\title{
Approaches of Current College English Curriculum Reform
}

\author{
Lige Qiao
}

Nanchang Institute of Science and Technology, Nanchang, 330108, China

Keywords: curriculum reform; problems; approaches; holistic curriculum.

\begin{abstract}
Curriculum is a key link between teaching concept and teaching practice. Curriculum reform is an important part in the reform of college English teaching and is an efficient way to improve its quality at the same time. However, the current college English reform exists many problems, such as dislocation of course function, absence of curriculum needs analysis, atomized curriculum structure and alienation of examination and so on so forth. Against those key problems, the paper explores some approaches of college English reform from the perspective of holistic curriculum.
\end{abstract}

\section{Introduction}

Curriculum reform is an important part in the reform of college English teaching and is an efficient way to improve its quality at the same time. To some extent, it plays an improving role to guide the college English curriculum reform. However, from the current situation, there are many problems, such as objective uncertainty in college curriculum, difficulty in shaking off exam-oriented education, inadaptation of the requirements of social development, especially the lack of integrity.

In this paper some approaches of college English reform from the perspective of holistic curriculum will be explored.

\section{Approaches of College English Reform under Holistic Curriculum}

Curriculum reform is an important part in the reform of college English teaching and is an efficient way to improve its quality at the same time. However, the current college English reform exists many problems, which can be manifested in the following areas. The concrete problems are as follows. such as dislocation of course function, absence of curriculum needs analysis, atomized curriculum structure and alienation of examination and so on so forth.

In order to overcome the problems of current college English reform, the author explores some approaches to reform College English from the perspective of Holistic Curriculum.

\section{Constructing Holistic Teaching Process}

According to the holistic curriculum theory, the comprehensive college English learning process should include the following five aspects, focusing on language nature, providing true language learning materials, creating real learning community, employing various cognitive learning methods and implementing integrated assessments. The author believes that the integrity of the learning process is mainly controlled by the integrity of the assessment. The existing CET4 and CET6 standardized test system severely erode the integrity of college English teaching process, which may cause the college English teaching process full of binary, isolated and atomic phenomena as well as the crux that made the courses function difficult to perform.

Therefore, the first step to build the holistic college English teaching process is to reform the CET4 and CET6. The reformed examine methods should focus on students as a whole person; the separated parts like isolated pronunciation, vocabulary, grammar, listening, speaking, reading, writing, translation... should be acquired comprehensively in true learning materials; the knowledge and meaning should not be constructed by the accumulation of language points, but rely on 
communication and experience in real community; students' multiple intelligence factors like different learning strategies and attitudes are bound to receive greater respect and tolerance.

What's more, learning time cannot be ignored. Many colleges may only focus on a certain class, day, week, month and semester and fails to take integration and convergence from high school to college into account. Therefore, the universities should fully consider the standard learning hours and flexible learning hours to develop short, medium and long-term learning plans to make a holistic school curriculum planning.

Finally, holistic curriculum pays much attention to the whole development process of the educational institutions, such as schools' educational purposes, course objectives, curriculum design, curriculum implementation and curriculum evaluation, rather than the one-sided phenomenon of individual class or a single course description. Therefore, all of the factors, such as the school curriculum research, planning, design, implementation and evaluation, need to be considered comprehensively and sustainably.

Thus, the true significance of teaching and college English curriculum is expected soon.

\subsection{Shaping Holistic Teachers}

The author conducted a survey of the teacher-student relationship and the English teachers' role in actual classroom teaching, and 28 college English teachers were involved in the survey below.

Table 1 A Survey of the English Teachers’ Role and the Teacher-Student Relationship in Actual Classroom Teaching

\begin{tabular}{|c|c|c|c|}
\hline & Category & Number & Proportion \\
\hline \multirow{3}{*}{ English Teachers' Role } & language explanation & 16 & $56 \%$ \\
\cline { 2 - 4 } & language demonstration & 8 & $29 \%$ \\
\cline { 2 - 4 } & language communication & 4 & $15 \%$ \\
\hline \multirow{2}{*}{$\begin{array}{c}\text { Teacher-Student } \\
\text { Relationship }\end{array}$} & $\begin{array}{c}\text { teaching and learning } \\
\text { relationship }\end{array}$ & 14 & $49 \%$ \\
\cline { 2 - 4 } & $\begin{array}{c}\text { language communication } \\
\text { relationship }\end{array}$ & 8 & $27 \%$ \\
\cline { 2 - 4 } & $\begin{array}{c}\text { communicative cooperation } \\
\text { relationship }\end{array}$ & 6 & $24 \%$ \\
\hline
\end{tabular}

The author found that most of the teachers' role in teaching is still language explanation (taking up 56\%) and language demonstration (accounting for 29\%), and the role in language communication accounts for only 15\%; in the teacher-student relationship, the teaching and learning relationship covers $49 \%$, and the relationship between language communication and communicative cooperation account for only $27 \%$ and $24 \%$ respectively.

We know the roles of language explanation and demonstration are difficult to trigger dialogue and interaction between teachers and students, and the relationship between teaching and learning is a true portrayal of dualism between teachers and students. Hence, the integrity of the teachers' role needs to be further improved.

Cultivating holistic teachers is very essential, and let's figure out the main features of holistic teachers: sincerity, presence and care.

Sincerity means overall consistency, which refers to a person's behavior consistent with his inner nature. Holistic teachers can teach in accordance with his/her own intrinsic nature. Holistic teachers should be sensitive to the needs of their students and meanwhile know quite well the challenges and possibilities that the world gives right now and right here.

The presence means teachers are not distracted by other things and can immerse themselves into teaching, and always communicate and interact with students. Therefore, teachers of these characteristics are extremely dedicated and selfless. What's more, when discussed the "teaching 
presence", a scholar once said, "I believe the prerequisite of real presence is an open mind. The teacher with an open mind will be more enthusiastic, independent, energetic and compassionate, and he is able to read students' body language and hear their feelings between the lines...”. If the teacher can put his soul back into the classroom, subjects he taught will be performed in vigor and he can enjoy his work and does his best at the same time.

Concern is the inevitable result of sincerity and presence. And it is one of the important methods to make connection between teachers and students. At the same time, caring in turn can make students feel the sincerity and presence of the teacher. Caring is a relationship, equipped with the precondition of the presence of both parties and the features of focus and shift motivation. When one really cares about a person, one would listen to him, watch him, feel him and be willing to accept all the information he delivers. When teachers show concern for students, students would feel their teacher-student relationship more closely linked.

Except for the above three features a holistic teacher should obtain, the teachers should also examine, observe, reflect and improve their own teaching behavior day after day, cultivating themselves at all-round level and shaping themselves into a real holistic teachers bit by bit.

New Oriental School achieves a great success in China. One reason may lie in one of its educational criteria - "Love, unconditional love for each student". The author used to be a part-time teacher in this English training center and found that the teachers there are kind but witty. They love and care their students but not spoil them. What's more, it will arrange teaching forum every week and teaching seminar every month. Each time, the teachers stand on the stage to demonstrate and to share, full of passion and creation. They always use such fashionable and creative ways to warn and inspire their students instead of criticizing them directly. Let's look at one typical example of their witty words below:

"A dota a day keeps girls away; A dota a day, makes you become a gay.”

\subsection{Turning to Holistic Learning (Deep Learning)}

Holistic learning is not only a way of teaching and learning, but a course constructive model. Traditional course controls what students learn, while holistic learning wants to establish a curriculum continuum and explores a variety of ways to make the world a common classroom, which means to make school re-contextualized. Under the holistic worldview, we humans are equal to other species in the world, and human exists as a self-reflection participant. John Miller called this "Holistic Learning" or "Deep Learning", because it affects the student's entire life and profoundly changes the stuff beyond the intellectuality.

Comprehensively and generally speaking, holistic learning involves the following main elements.

\subsubsection{Comprehensive Learning Process}

Learning is not a mere intellectual development process. It also directly touches so much of the other aspects of our lives. Like any ecosystem, as if one aspect of our existence is ignored, then undoubtedly, this will affect our entire body and mind system. For example, children tend to learn through the way of movements or actions. The denial of this kind of body requirements for the children's intellectual development is obviously harmful.

\subsubsection{Various Cognitive Learning Styles}

For a long time, school education has been only concerned about students' language, logic and rational abilities and ignoring the other cognitive ways. Holistic learning tries to integrate various cognitive and learning methods. Let's refer to the following table, the various cognitive and learning methods are arbitrarily classified by their characteristics. 
Table 2 Various Cognitive Learning Styles

\begin{tabular}{|c|c|}
\hline Body Movement & Gymnastics, dance, sing, Yoga, Taiji, outdoor activities, etc. \\
\hline Emotion & Various recovery therapies, entertainment, dating, etc. \\
\hline Perception & Imagination, arts, hypnosis therapy, etc. \\
\hline Mind & Story creation, legend, literature, diary, etc. \\
\hline Spirituality & Meditation, Christianity, Lamaism, Buddhism, etc. \\
\hline Group Task & Collaborative study, social and community activities, etc. \\
\hline Comprehensive Task & Indigenous education, TV series, etc. \\
\hline
\end{tabular}

This is because, in fact, a variety of methods are simultaneously applied to the certain aspects of body, emotion, mind and spirit and they can be mixed up. For example, outdoor activities and imagination are simultaneously applied to one's personality. During outdoor activities, inadequate physical conditions are in the lift, at the same time, emotional state is also changing. Even in meditation, not only consciousness occurs, but also body purifies and emotions calm down.

\subsubsection{Providing a Psychological Safe Environment}

Researches find that when we are in a trusted environment, we learn best. If a person feels the environment is safe, then he is more willing to take risks and try. On the contrary, if he felt a threat, then he tends to step back and do nothing good for learning.

\subsubsection{Taking initiatives to try and operate}

Initiative try and manipulation not only help to enrich the learning experience, but also help to get feedback of one's own performance. Especially the earning skills, one must have the opportunity and courage to operate them under different conditions.

\subsubsection{Establishing links to real life situations}

When we see what we have learned in our lives, we will learn best. Holistic learning seeks to make connection between schools and the surrounding world. The knowledge gained in school should not be separated from human life, but links vividly lie in every possible situations.

\subsubsection{Intuition}

Over the years, the curriculum area has been emphasizing reasoning while ignoring intuition. Students rarely have the opportunity to develop their inner, imaginative responses, which causes them too dependent, lack of independent and innovative spirit. Emphasizing intuition is to pay attention to thoughts, feelings, imagination and other inner experience rather than external awareness. In order to restore the balance between intuition and reasoning, we need to give more priority to the arts and sports as well as other methods in favor of intuitive thinking.

\section{Conclusion}

The study on college English reform from the perspectives of holistic curriculum theory may provide new methods for the college English reform and give some inspiration to the curriculum reform area. It is expected that this thesis will make contribution to the study of the college English reform and other related fields and provide some enlightenment and inspiration for curriculum reform area. 


\section{References}

[1] Dewey,J .Experience and Education[M].New York: Macmillan,1969: 88.

[2] Flake, C.L.Holistic Education: Principles, Perspectives and Practices [M]. Brandon: Holistic Education Press, 1993, Appendix A.

[3] Halliday M A K. Learning How to Mean: Exploration in the Development of Language [M]. London: Edward Arnold, 1975.

[4] Long, M. H. Second Language Needs Analysis [M]. Cambridge: Cambridge University Press, 2005.

[5] Miller, R. Caring for New Life: Essays on Holistic Education [M]. Brandon: Foundations for Education Renewal, 2000.

[6] Miller, R. Make Connections to the World: Some Thoughts on Holistic Curriculum [J]. Encounter: Education for Meaning and Social Justice, 2001, (14)4.

[7] Miller, R. New Directions in Education. Brandon: Holistic Education Press, 1991.

[8] Miller, R. The Renewal of Meaning in Education. Brandon: Holistic Education Press, 1993.

[9] Miller. J. P. The Holistic Curriculum (revised and expanded edition) [M]. Toronto: OISE Press, 2001.

[10] Miller, J. P. Holistic Teacher [M]. Toronto: OISE Press, 1993.

[11] Nunan, D. Syllabus Design [M]. Oxford: Oxford University Press, 1991.

[12] Nunan, D. The Learner-centered Curriculum [M]. Cambridge: Cambridge University Press, 1988.

[13] Nielsen T.W. Rudolf Steiner's Pedagogy of Imagination: A case Study of Holistic Education [M]. Bern: Lang Press, 2004.

[14] Richards, J. C. et a1. Longman Dictionary of Language Teaching and Applied Linguistics [z]. London: Longman Group UK Limited, 1992.

[15] Weaver C. Understanding Whole Language: From Principles to Practice [M]. Portsmouth, N. H.: Heinemann, 1990.

[16] Weaver C. Reading Process and Practice: From Socio-psycholinguistics to Whole Language [M]. Portsmouth, N. H.: Heinemann, 1988. Widdowson HG. Aspects of Language Teaching [M].Oxford: Oxford University Press, 2nd ed. 1991. 